\title{
Horticulture Development in Nepal: Prospects, Challenges and Strategies
}

\author{
Mohan Bahadur Thapa ${ }^{1, *}$, Sanjay Dhimal ${ }^{2}$ \\ ${ }^{1}$ Department of Agriculture, Harihar Bhawan, Nepal \\ ${ }^{2}$ Ministry of Agriculture Development, Singhdurbar, Nepal
}

Copyright $@ 2017$ by authors, all rights reserved. Authors agree that this article remains permanently open access under the terms of the Creative Commons Attribution License 4.0 International License

\begin{abstract}
Nepal has different ecological belts endowed with different types of climates due to its geographical locations for the production of horticultural crops. Government organizations were not in existence for the development of horticulture sector before 1950, yet growing of fruits, vegetables, spices and flowers started from time immemorial in private sector. After the creation of Department of Horticulture during sixties several horticulture farms were established in different agro-ecological zones where research and extension programs were launched and horticulture development took momentum. There is tremendous scope for commercial horticultural crops production to enter into the international market. Due to subsistence farming system, poor infra-structure, transportation facilities, linkage to the international market and technical know-how, horticulture development could not gain momentum as expected. The productivity of horticultural crops comparing with two giant neighboring countries i.e. China and India does not give matching results but in case of spices especially in large cardamom, Nepal's productivity is higher than these two countries. Large cardamom, ginger, tea and coffee have played significant role in trade balance while in case of fruits, flowers and some of the fresh vegetables Nepal faces still trade deficit.
\end{abstract}

Keywords Infrastructure, Niche Product, Indigenous, Exotic, Export, Import, Trade Balance

\section{Introduction}

Nepal is situated as trapezoidal shape $870 \mathrm{~km}$ in length by $130 \mathrm{~km}$ in width. Its total area is 1,47,181 sq. $\mathrm{km}$. In latitude, it ranges from $26^{\circ} 22^{\prime}$ to $30^{\circ} 27^{\prime} \mathrm{N}$ and in longitude from $80^{\circ} 04^{\prime}$ to $88^{\circ} 12^{\prime} \mathrm{E}$, Agriculture Diary 2015 [1]. In altitude ranges from about $60 \mathrm{~m}$ above mean sea level in the Terrain (Kechna Kabal, Jhapa District) in the South-East to 8,848masl at the summit of Mount Everest in the North. It is surrounded by China in the north and India in the east, west and south. It has favorable agro ecological diversity for agricultural production, especially in the horticulture sector. Different ecological belts are endowed with different types of climates due to its geographical locations. Most of the important fruits, vegetables, spices and flowers of the world can be grown in this country. Three distinct seasons experienced are hot and dry season from March to mid-June, wet summer from mid-June to September and dry and cold season from October to February. The unique agro-ecological zones favored by altitudes, topography, and aspect within the country offer an immense opportunity for growing different types of fruits, vegetables, flowers, spices and other plantation crops. Nepal is rich in biodiversity as wild plants of mandarin in Mangtewa, custard apple in Dhankuta in the east while Amla (Indian gooseberry) plants in Jasbire way to Indrawati, wild citron in mid hill of central region and wild olive plants are found in Humla and Kalikot, the western part of Nepal. Actually, Nepal is the land of wonder with agro-climatic variability, NHS 2016 [6].

Horticulture development at the government level started during sixties when the Horticulture Division was created in the newly established Department of Agriculture in 1952. Many farms were established during sixties, commodity development divisions were established in seventies, agricultural research was given a special focus and a separate research wing named Nepal Agricultural Research Council (NARC) was formed in the year 1993, Poudyal et al. [7].

In the last sixty years, there have been significant progresses in policy development, institutional development, and technology generation and transfer. With Nepal's membership to WTO and regional trade associations, increasing education levels and nutrition knowledge of the people, increasing demand and import of horticultural commodities shows high prospects for horticulture development and to harness the potentiality of horticultural development in Nepal experience shows that there are challenges for enhancing production, improving physical infrastructure, enhancing marketing and promotion of 
processed products. In Nepal, 65.5\% population are engaged in agriculture and its contribution to national GDP is 31.23\% where horticulture sub-sector has the most significant role in AGDP which shares 21.42 percent, MOAD 2015 [5].

\section{Historical Background}

Horticulture was limited to growing indigenous fruits and vegetables before 1950 in the private sector, while collection and growing of fancy plants existed in the palaces of Rana Prime Ministers and their families. Government organizations were not in existence before fifties, yet growing of horticultural crops like fruits, vegetables, spices and flowers started from time immemorial. In an ancient period Nepalese people used to cultivate indigenous fruits like guava, pear, peach, citrus; vegetables like radish, mustard leaf, red turnip, cucurbits; spices like coriander, onion, garlic, fenugreek; flowers like marigold, cactus, wild rose etc. Similarly, fancy and exotic horticultural plants such as persimmon, loquat, peach, pear and fig; flowering plants like coral, magnolia, China rose, and evergreen plants like exotic pines, monkey puzzle plants etc. were collected and grown in Putali Bagaincha, Kathmandu.

After the creation of Department of Horticulture during sixties several horticulture farms were established in different agro-ecological zones with the support of Indian Cooperation Mission (ICM). German government (GTZ) supported Gandaki Zone Agriculture Development Project (GADP) was started in 1969 that had a significant component on horticulture development. Similarly, Japan government (JICA) helped to establish Janakpur Zone Agriculture Development Project (JADP) in 1973 and has impact in the development of Junar (Sweet Orange) in Sindhuli and Ramechhap district of Nepal. Food and Agriculture Organization (FAO) supported Hill Agriculture Development Project (HADP) was started in 1973 strengthened the established horticulture farms of Nepal. Karnali Bheri Integrated Rural Development (KBIRD) Project supported by Canadian government (CIDA) included the horticulture component in their programs. British government (UK/ODA) supported Koshi Hill Rural Area Development Project (KHARDEP) was started in 1981 and has the impact in orchard development in citrus and vegetable seed production in the east. JICA supported Horticulture Development Project (HDP) was started in 1985 to develop fruit sub-sector in the central region of Nepal whereas ADB supported Hill Fruit Development Project (HFDP) was started in 1987 to develop citrus fruit in the eastern mid-hill region of Nepal. Nepal Horticultural Society (NHS) was established officially in 1990 to enhance public awareness towards the importance of horticulture and to promote linkages with national and international institutions. After two years of its establishment, Floriculture Association of Nepal (FAN), a private sector organization was also started functioning in the field of flower sub-sector development. Tea and Coffee Development Board was established in 1993 to develop tea and coffee sub-sector in the country.

Then onwards there have not been major changes in the organizational setup but there are ongoing projects implementing by Ministry of Agricultural Development: High Value Agriculture Project for Hill and Mountains (HVAP) with the financial support of IFAD for the value chain development in apple, off-season vegetables, ginger, turmeric and vegetable seeds; Project for Agriculture Commercialization and Trade (PACT) with the financial support of WB for the commercialization of coffee, cardamom, ginger, fresh vegetable, and kiwi; Raising Income of Small and Medium Farmers Project (RISMFP), Hill and Mountain Agricultural Livelihood Improvement Project (HIMALI) and Rani Jamara Kuleria Irrigation Project (RJKIP) and other non-governmental organizations are also involving to develop the whole horticulture sector, NHS 2016 [6].

\section{Situation of Horticultural Crops}

\subsection{Vegetables}

During the last 10 years, area of vegetable crops has increased by about $41 \%$ from 189,832 in $2005-06$ to 266,937 hectares in 2014-15 whereas the production has increased by about 63\% from 2,190,100 MT in 2005-06 to 3,580,085 MT in 2014-15 as shown in table 1 and figure 1.

Table 1. Area, production and productivity of vegetables in Nepal

\begin{tabular}{|c|c|c|c|}
\hline Year & Area (Ha) & $\begin{array}{c}\text { Production } \\
\text { (MT) }\end{array}$ & $\begin{array}{c}\text { Productivity } \\
\text { (MT/Ha) }\end{array}$ \\
\hline $2005 / 06$ & 189832 & 2190100 & 11.54 \\
\hline $2006 / 07$ & 191922 & 2298689 & 11.98 \\
\hline $2007 / 08$ & 208108 & 2538904 & 12.20 \\
\hline $2008 / 09$ & 225154 & 2754406 & 12.23 \\
\hline $2009 / 10$ & 235098 & 3003821 & 12.78 \\
\hline $2010 / 11$ & 244102 & 3203563 & 13.12 \\
\hline $2011 / 12$ & 245037 & 3298816 & 13.46 \\
\hline $2012 / 13$ & 246392 & 3301684 & 13.40 \\
\hline $2013 / 14$ & 254932 & 3421035 & 13.42 \\
\hline $2014 / 15$ & 266937 & 3580085 & 13.41 \\
\hline
\end{tabular}

Source: MoAD, 2005/06-2014/15 [5]

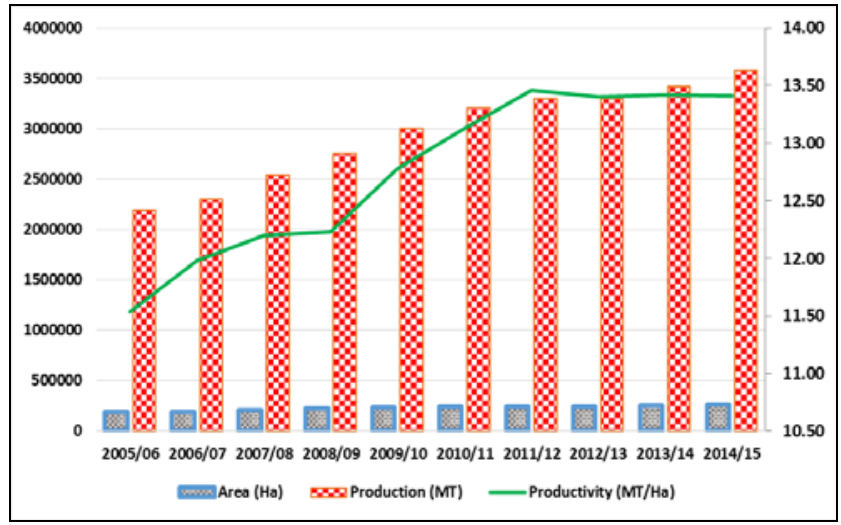

Figure 1. Trend of area, production and productivity of vegetables 


\subsection{Fruits}

Table 2 and figure 2 shows that during the last 10 years, area of fruits has increased by about $64 \%$ from 91,923 in 2005-06 to 261,739 ha in 2014-15 whereas the production has increased by about 85\% from 535,449 MT in 2005-06 to 1,762,617 MT in 2014-15.

Table 2. Area, production and productivity of fruits in Nepal

\begin{tabular}{|c|c|c|c|c|}
\hline Year & $\begin{array}{c}\text { Total } \\
\text { Area (Ha) }\end{array}$ & $\begin{array}{c}\text { Productive } \\
\text { Area } \\
\text { (Ha) }\end{array}$ & $\begin{array}{c}\text { Production } \\
\text { (MT) }\end{array}$ & $\begin{array}{c}\text { Productivity } \\
\text { (MT/Ha) }\end{array}$ \\
\hline $2005 / 06$ & 91923 & 56549 & 535449 & 9.47 \\
\hline $2006 / 07$ & 94901 & 57595 & 575095 & 9.99 \\
\hline $2007 / 08$ & 100099 & 63432 & 630563 & 9.94 \\
\hline $2008 / 09$ & 103651 & 68785 & 686213 & 9.98 \\
\hline $2009 / 10$ & 107322 & 70722 & 706972 & 10.00 \\
\hline $2010 / 11$ & 117932 & 79184 & 794165 & 10.03 \\
\hline $2011 / 12$ & 139321 & 101233 & 1029754 & 10.17 \\
\hline $2012 / 13$ & 137759 & 101480 & 938730 & 9.25 \\
\hline $2013 / 14$ & 150150 & 110617 & 979542 & 8.86 \\
\hline $2014 / 15$ & 150387 & 110802 & 992703 & 8.96 \\
\hline
\end{tabular}

Source: MoAD, 2005/06-2014/15 [5]

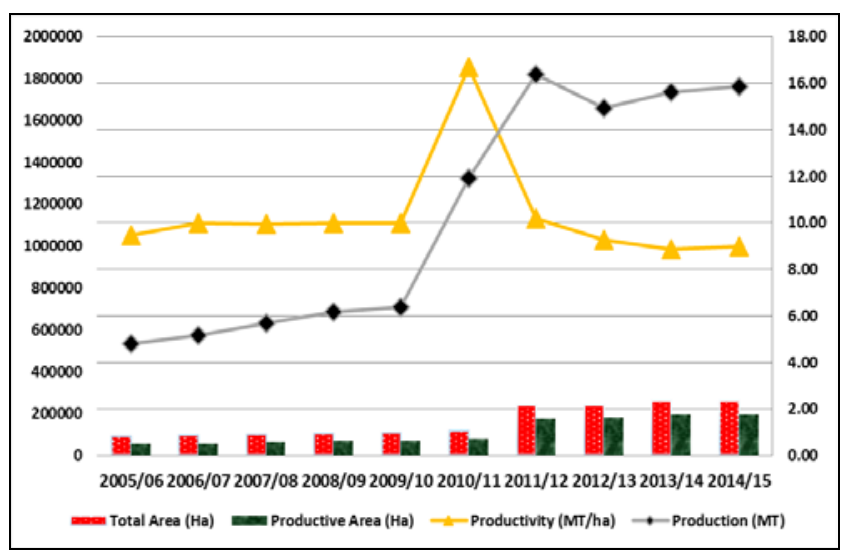

Figure 2. Trend of area, production and productivity of fruits

\subsection{Potatoes}

During last 10 years, area and production of potatoes have been increased by about 31\% from 150,864 to 197037 ha and from 1,974,755 MT to 2,586,287 MT respectively.

Table 3. Area, production and productivity of potatoes in Nepal

\begin{tabular}{|c|c|c|c|}
\hline Year & Area (Ha) & $\begin{array}{c}\text { Production } \\
\text { (MT) }\end{array}$ & $\begin{array}{c}\text { Productivity } \\
\text { (MT/Ha) }\end{array}$ \\
\hline $2005 / 06$ & 150864 & 1974755 & 13.09 \\
\hline $2006 / 07$ & 153534 & 1943246 & 12.66 \\
\hline $2007 / 08$ & 156737 & 2054817 & 13.11 \\
\hline $2008 / 09$ & 181900 & 2424048 & 13.33 \\
\hline $2009 / 10$ & 185342 & 2517696 & 13.58 \\
\hline $2010 / 11$ & 182600 & 2508044 & 13.74 \\
\hline $2011 / 12$ & 190250 & 2584301 & 13.58 \\
\hline $2012 / 13$ & 197234 & 2690421 & 13.64 \\
\hline $2013 / 14$ & 205725 & 2817512 & 13.70 \\
\hline $2014 / 15$ & 197037 & 2586287 & 13.13 \\
\hline
\end{tabular}

Source: MoAD, 2005/06-2014/15 [5]

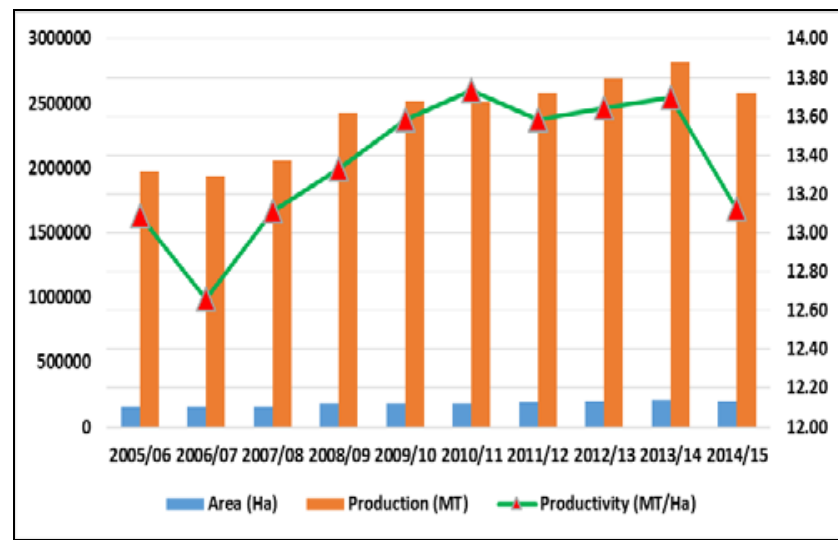

Figure 3. Trend of area, production and productivity of potatoes

\subsection{Spices}

During last decades, area of spice crops has increased by about $64 \%$ from 35,956 in 2005-06 to 58,960 ha in 2014-15 whereas the production has increased by about $78 \%$ from 226,914 MT in 2005-06 to 404,420 MT in 2014-15 as shown in table 4 and figure 4 .

Table 4. Area, production and productivity of spices in Nepal

\begin{tabular}{|c|c|c|c|}
\hline Year & $\begin{array}{c}\text { Area } \\
\text { (Ha) }\end{array}$ & $\begin{array}{c}\text { Production } \\
\text { (MT) }\end{array}$ & $\begin{array}{c}\text { Productivity } \\
\text { (MT/Ha) }\end{array}$ \\
\hline $2005 / 06$ & 35956 & 226914 & 6.31 \\
\hline $2006 / 07$ & 37547 & 248644 & 6.62 \\
\hline $2007 / 08$ & 38980 & 243210 & 6.24 \\
\hline $2008 / 09$ & 42756 & 276445 & 6.47 \\
\hline $2009 / 10$ & 45744 & 320143 & 7.00 \\
\hline $2010 / 11$ & 47867 & 323870 & 6.77 \\
\hline $2011 / 12$ & 48848 & 364915 & 7.47 \\
\hline $2012 / 13$ & 47770 & 345216 & 7.23 \\
\hline $2013 / 14$ & 57639 & 429709 & 7.46 \\
\hline $2014 / 15$ & 58960 & 404420 & 6.86 \\
\hline
\end{tabular}

Source: MoAD, 2005/06-2014/15 [5]

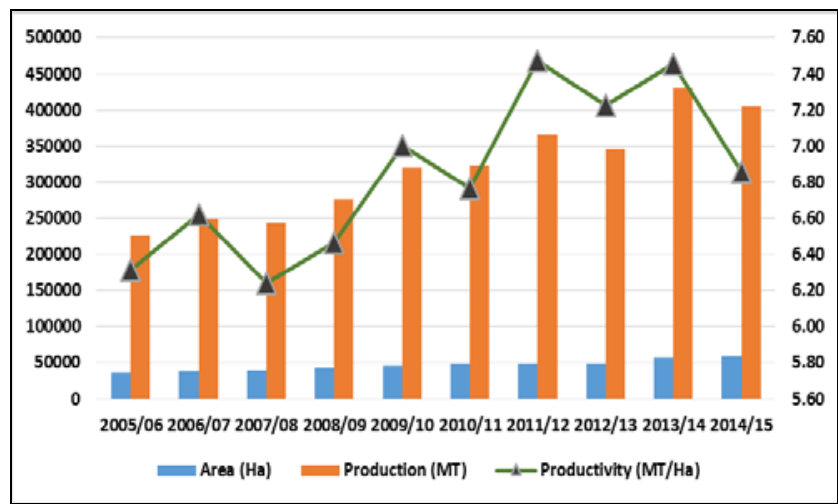

Figure 4. Trend of area, production and productivity of spices 


\subsection{Tea}

During the last 5 years, area of tea has increased by about $50 \%$ from 17,451 ha in $2010-11$ to 26,165 ha in $2014-15$ whereas the production has increased by about 33\% from 17,438 MT in 2010-11 to 23,187 MT in 2014-15 as shown in table 5 and figure 5 .

Table 5. Area, production and productivity of tea in Nepal

\begin{tabular}{|c|c|c|c|}
\hline Year & $\begin{array}{c}\text { Area } \\
\text { (Ha) }\end{array}$ & $\begin{array}{c}\text { Production } \\
\text { (MT) }\end{array}$ & $\begin{array}{c}\text { Productivity } \\
\text { (MT/Ha) }\end{array}$ \\
\hline $2010 / 11$ & 17451 & 17438 & 1.00 \\
\hline $2011 / 12$ & 18149 & 18726 & 1.03 \\
\hline $2012 / 13$ & 19036 & 20588 & 1.08 \\
\hline $2013 / 14$ & 19271 & 21394 & 1.11 \\
\hline $2014 / 15$ & 26165 & 23187 & 0.89 \\
\hline
\end{tabular}

Source: MoAD, 2010/11-2014/15 [5]

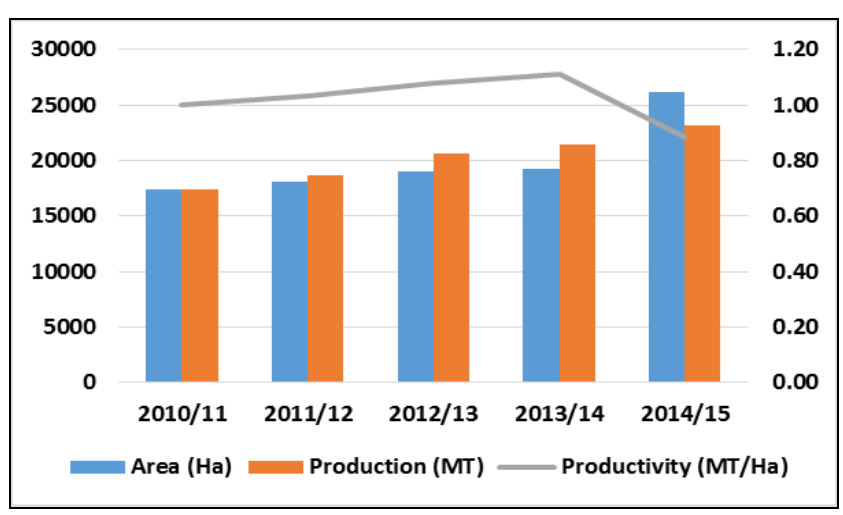

Figure 5. Trend of area, production and productivity of tea

\subsection{Coffee}

During the last 5 years, area of coffee has been increased by about $49 \%$ from 1,752 ha in $2010-11$ to 2,618 ha in 2014-15 whereas the production (green beans) has been increased by about 8\% from 402 MT in 2010-11 to 434 MT in 2014-15 as shown in table 6 and figure 6 . The area and production is in increasing trend but the productivity is slightly decreasing due to the reason that new plantation for area expansion is increasing but the coffee plants haven't come into fruiting stage yet.

Table 6. Area, production and productivity of coffee in Nepal

\begin{tabular}{|c|c|c|c|}
\hline Year & $\begin{array}{c}\text { Area } \\
\text { (Ha) }\end{array}$ & Production (MT) & $\begin{array}{c}\text { Productivity } \\
\text { (MT/Ha) }\end{array}$ \\
\hline $2010 / 11$ & 1752 & 402 & 0.23 \\
\hline $2011 / 12$ & 1780 & 425 & 0.24 \\
\hline $2012 / 13$ & 1750 & 366 & 0.21 \\
\hline $2013 / 14$ & 1911 & 429 & 0.22 \\
\hline $2014 / 15$ & 2618 & 434 & 0.17 \\
\hline
\end{tabular}

Source: MoAD, 2010/11-2014/15 [5]

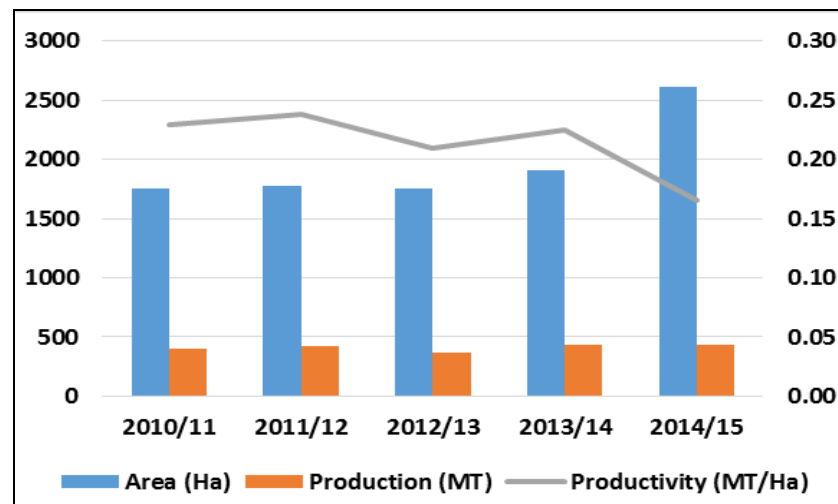

Figure 6. Trend of area, production and productivity of coffee

\subsection{Flowers}

During the last five years, area of flower has increased by about 34\% from 110 in 2010-11 to 147 ha in 2014-15 whereas the production has increased by about $47 \%$ from 90,990 thousand pieces in $2010-11$ to 134,138 thousand pieces in 2014-15 as shown in table 7 and figure 7.

Table 7. Area, production and productivity of flowers in Nepal

\begin{tabular}{|c|c|c|c|}
\hline Year & $\begin{array}{c}\text { Area } \\
\text { (Ha) }\end{array}$ & $\begin{array}{c}\text { Production ('000 } \\
\text { Pcs.) }\end{array}$ & $\begin{array}{c}\text { Productivity ('000 } \\
\text { Pcs./Ha) }\end{array}$ \\
\hline $2010 / 11$ & 110 & 90990 & 827.18 \\
\hline $2011 / 12$ & 120 & 105320 & 877.67 \\
\hline $2012 / 13$ & 137 & 115570 & 843.58 \\
\hline $2013 / 14$ & 141 & 127750 & 906.03 \\
\hline $2014 / 15$ & 147 & 134138 & 912.50 \\
\hline
\end{tabular}

Source: MoAD, 2010/11-2014/15 [5]

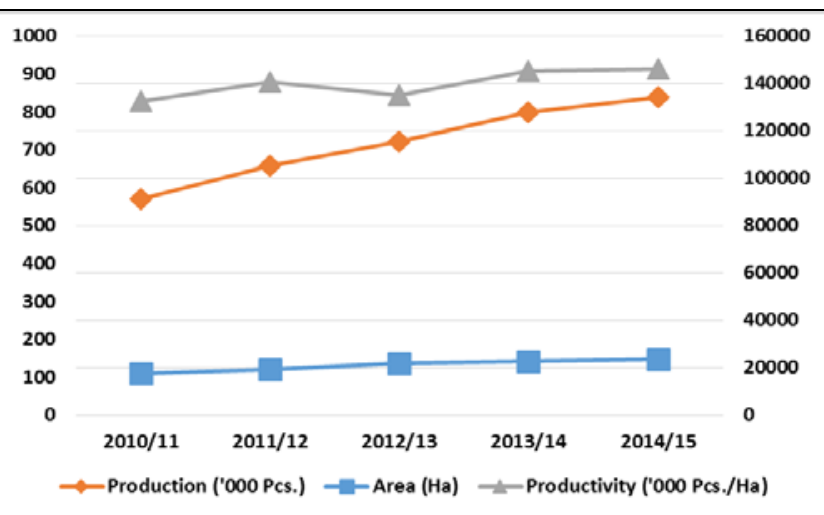

Figure 7. Trend of area, production and productivity of flowers

\section{Export and Import Scenario}

\subsection{Fruits}

In total export, share of summer fruits is $96 \%$ followed by citrus fruits (3\%) and winter fruits (1\%) by volume while by values summer fruits cover almost 100 percent and citrus and winter fruits are in insignificant amount whereas in total 
import, share of summer fruits is $59 \%$ followed by citrus fruits $(16 \%)$ and winter fruits (25\%) by volume while by values summer fruits cover $65 \%$ followed by citrus fruits (14\%) and winter fruits (21\%). Table 8 illustrates that the import of fruits by volume and values is more than the export which expels that this sub-sector should be emphasized.

\subsection{Vegetables}

In total export, share of fresh vegetables is $88 \%$ followed by potatoes (12\%) and dried vegetables in insignificant quantity by volume while by values fresh vegetables cover $64 \%$ followed by dried vegetables (22\%) and potatoes (14\%) whereas in total import, share of fresh vegetables is $34 \%$ followed by potatoes (54\%) and dried vegetables $(12 \%)$ by volume while by values fresh vegetables cover $33 \%$ followed by potatoes (41\%) and dried vegetables (26\%). Table 9 demonstrates that the import of vegetables by volume and values is more than the export which interprets that attention should be paid in the promotion of vegetable sub-sector for exportable commodities.

\subsection{Spices}

In total export, share of ginger is $83 \%$ followed by big cardamom (10\%), cinnamon (6\%), garlic (1\%) and other spices in insignificant quantity by volume while by values big cardamom covers $86 \%$ followed by ginger (10\%), cinnamon (3\%), garlic (1\%) and other spices in insignificant amount whereas in total import, share of other spices is $68 \%$ followed by garlic (30\%), ginger (1\%), cinnamon (1\%) and big cardamom in insignificant quantity by volume while by values other spices cover $83 \%$ followed by garlic (14\%), ginger (2\%), cinnamon (1\%) and big cardamom in insignificant amount. Here, other spices cover fenugreek, chilies, turmeric, pepper, coriander, cloves, cumin and small cardamom. Table 10 explains that export of spices by volume and values is little bit more than the import where big cardamom plays significant role while in the other spices sector a lot of progress have to be performed, Thapa et al. [8].

\subsection{Tea}

In total export, share of black tea is almost $100 \%$ where green tea is in insignificant quantity by volume while by values black tea covers $99 \%$ and green tea $1 \%$ whereas in total import, share of black tea and green tea is $99 \%$ and $1 \%$ respectively by volume and values. Table 11 shows that export of tea by volume and values is more than the import which reflects the positive sign for the development of tea sub-sector.

Table 8. Import and Export of Fruits to and from Nepal

\begin{tabular}{|c|c|c|c|c|c|c|}
\hline \multirow{2}{*}{ Fruits } & \multicolumn{3}{|c|}{ Import } & \multicolumn{3}{c|}{ Export } \\
\cline { 2 - 7 } & $\begin{array}{c}\text { Volume } \\
\text { (MT) }\end{array}$ & $\begin{array}{c}\text { Values } \\
\text { (Million NRs.) }\end{array}$ & $\begin{array}{c}\text { Values (Million } \\
\text { USD) }\end{array}$ & $\begin{array}{c}\text { Volume } \\
\text { (MT) }\end{array}$ & $\begin{array}{c}\text { Values } \\
\text { (Million NRs.) }\end{array}$ & $\begin{array}{c}\text { Values } \\
\text { (Million USD) }\end{array}$ \\
\hline Summer fruits & 110765 & 6879.60 & 67.45 & 15824 & 2841.63 & 27.86 \\
\hline Citrus Fruits & 30242 & 1406.89 & 13.79 & 452 & 5.27 & 0.05 \\
\hline Winter Fruits & 48151 & 2243.15 & 21.99 & 146 & 3.50 & 0.03 \\
\hline Total & 189158 & 10529.64 & 103.23 & 16422 & 2850.40 & 27.95 \\
\hline
\end{tabular}

Source: SINA 2015 [4]

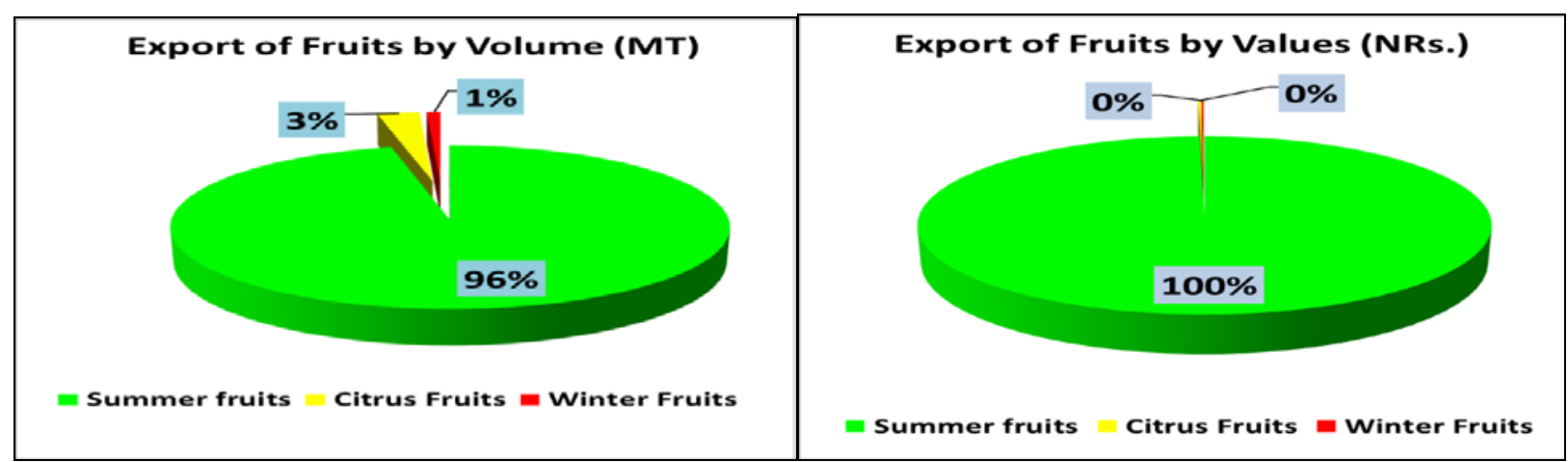



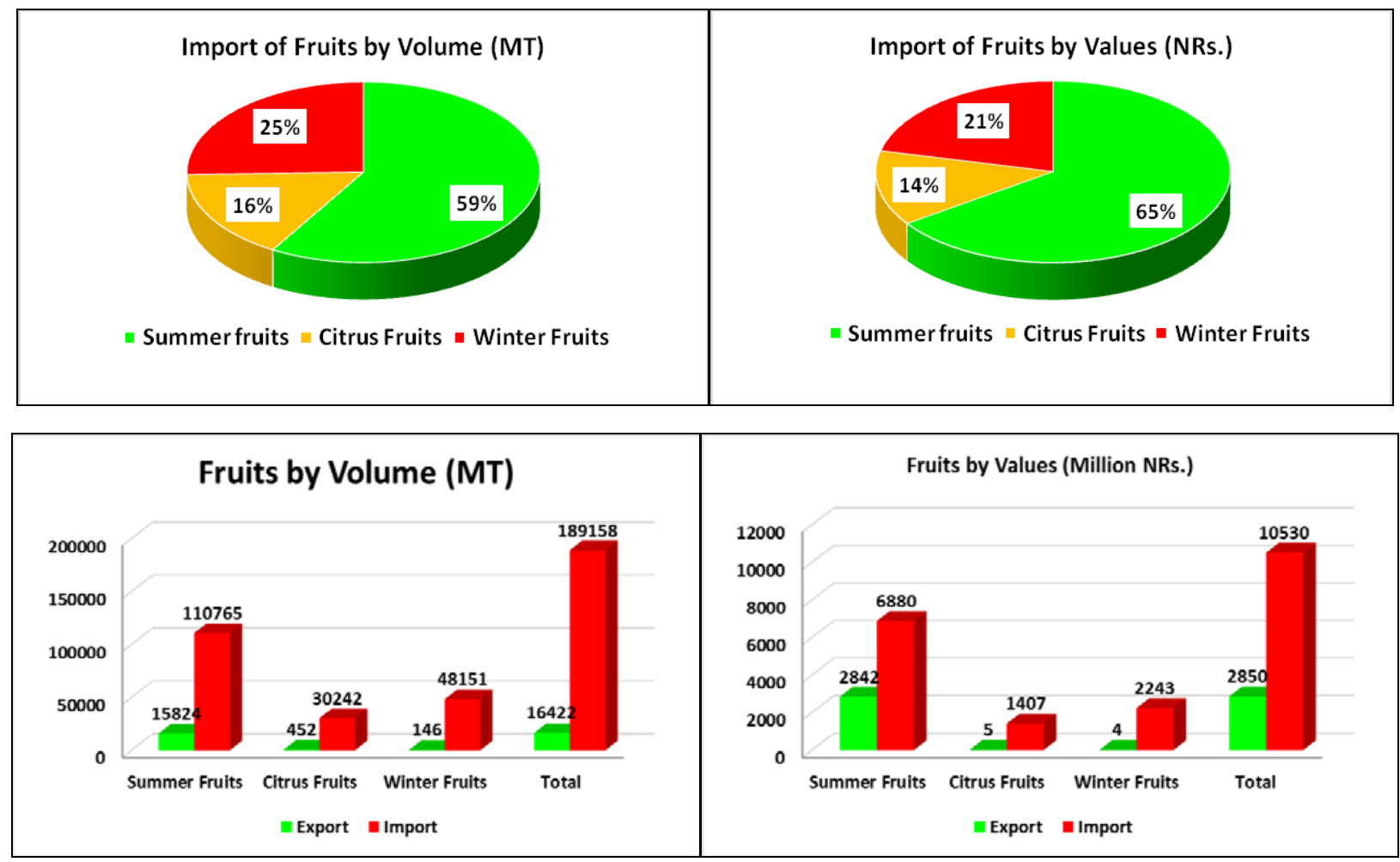

Figure 8. Export and import of fruits by volume and values

Table 9. Import and Export of Vegetables to and from Nepal

\begin{tabular}{|c|c|c|c|c|}
\hline \multirow{2}{*}{ Vegetables } & \multicolumn{2}{|c|}{ Import } & \multicolumn{2}{c|}{ Export } \\
\cline { 2 - 5 } & Volume (MT) & Values (NRs.) & Volume (MT) & Values (NRs.) \\
\hline Fresh Vegetables & 151848 & 4065783944 & 18174 & 182120621 \\
\hline Dried Vegetables & 55768 & 3311806438 & 50 & 60696953 \\
\hline Potatoes & 241719 & 5127904375 & 2426 & 39945434 \\
\hline Total & $\mathbf{4 4 9 3 3 5}$ & $\mathbf{1 2 5 0 5 4 9 4 7 5 7}$ & $\mathbf{2 0 6 5 0}$ & $\mathbf{2 8 2 7 6 3 0 0 8}$ \\
\hline
\end{tabular}

Source: SINA 2015 [4], (1USD $\cong 102$ NRs.)

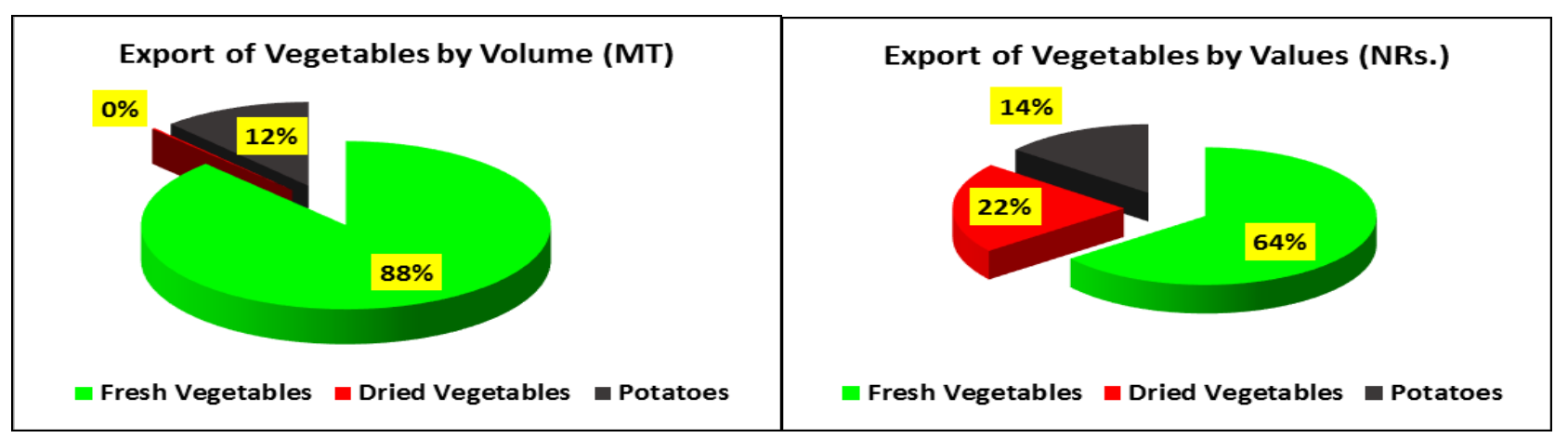




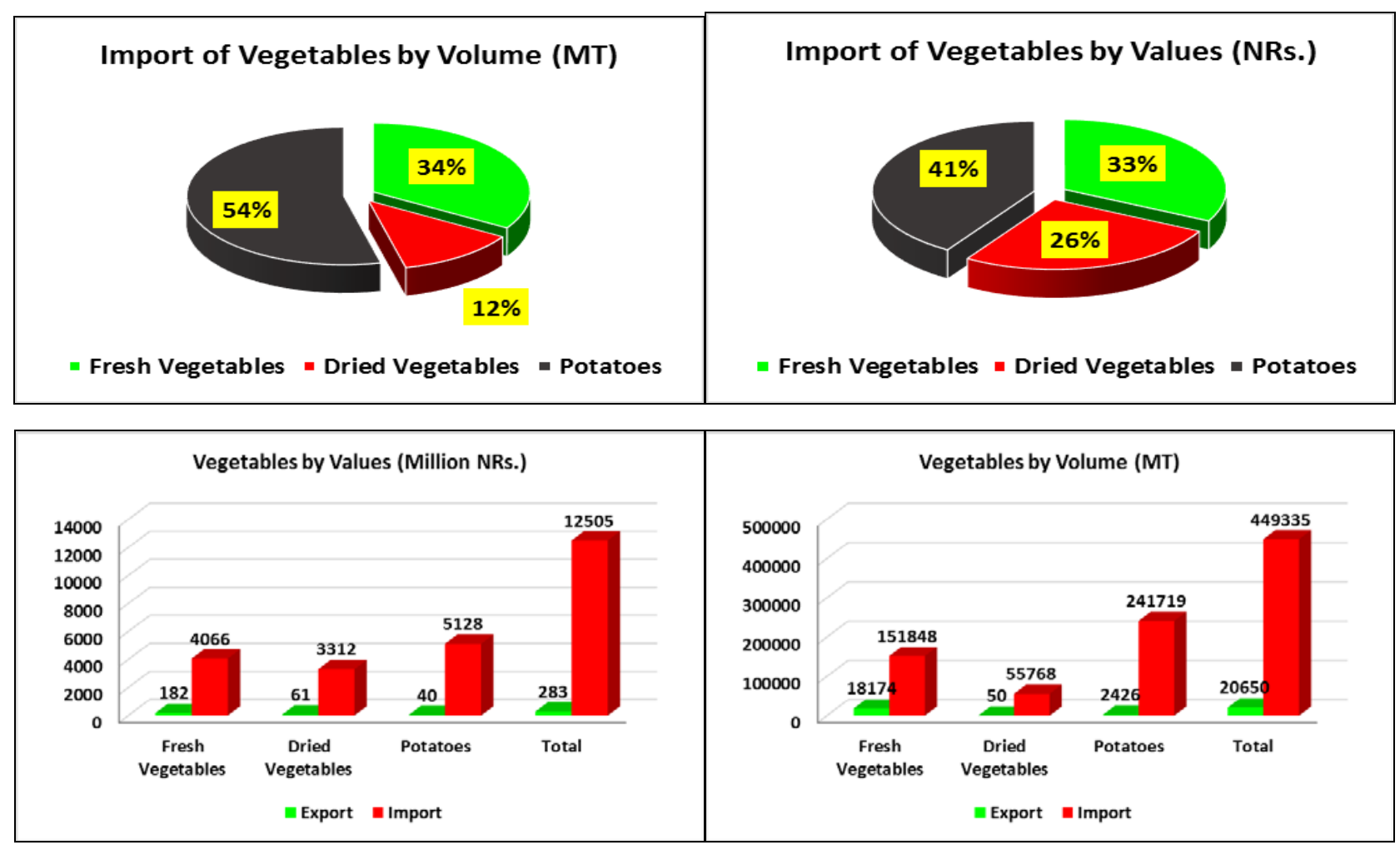

Figure 9. Export and import of vegetables by volume and values

Table 10. Import and Export of Spices to and from Nepal

\begin{tabular}{|c|c|c|c|c|}
\hline \multirow{2}{*}{ Spices } & \multicolumn{2}{|c|}{ Import } & \multicolumn{2}{c|}{ Export } \\
\cline { 2 - 5 } & Volume (MT) & Values (NRs.) & Volume (MT) & Values (NRs.) \\
\hline Ginger & 248 & 86951136 & 24549 & 464921376 \\
\hline Big Cardamom & 11 & 8599466 & 2930 & 3839810569 \\
\hline Cinnamon & 335 & 54313688 & 1715 & 132243022 \\
\hline Garlic & 8440 & 599133942 & 287 & 23431038 \\
\hline Other spices & 19611 & 3683313025 & 87 & 14047623 \\
\hline Total & $\mathbf{2 8 6 4 5}$ & $\mathbf{4 4 3 2 3 1 1 2 5 7}$ & $\mathbf{2 9 5 6 8}$ & $\mathbf{4 4 7 4 4 5 3 6 2 8}$ \\
\hline
\end{tabular}

Source: SINA 2015 [4], (1USD $\cong 102$ NRs.)

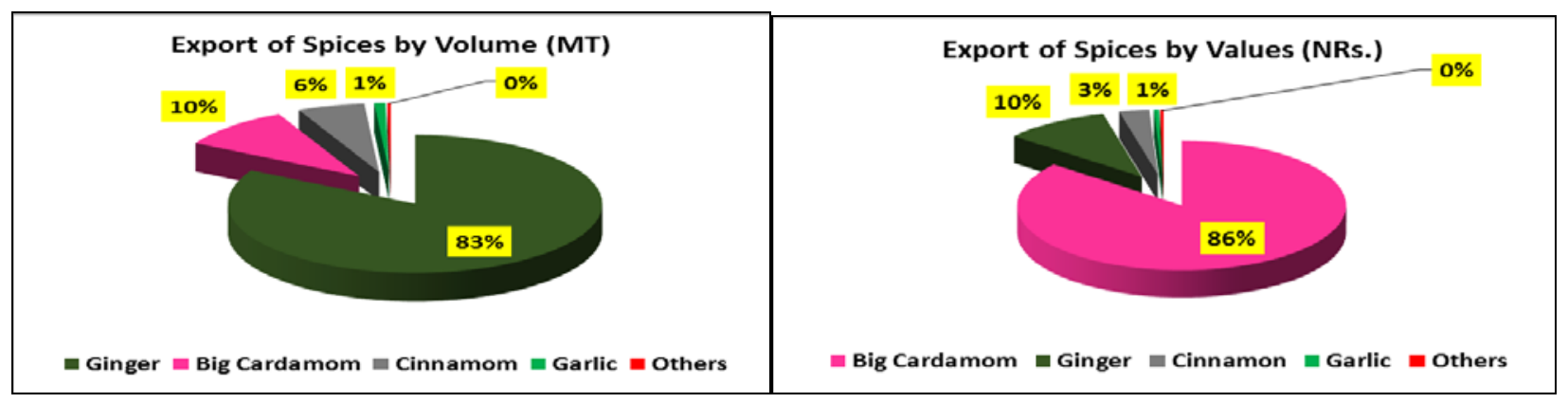




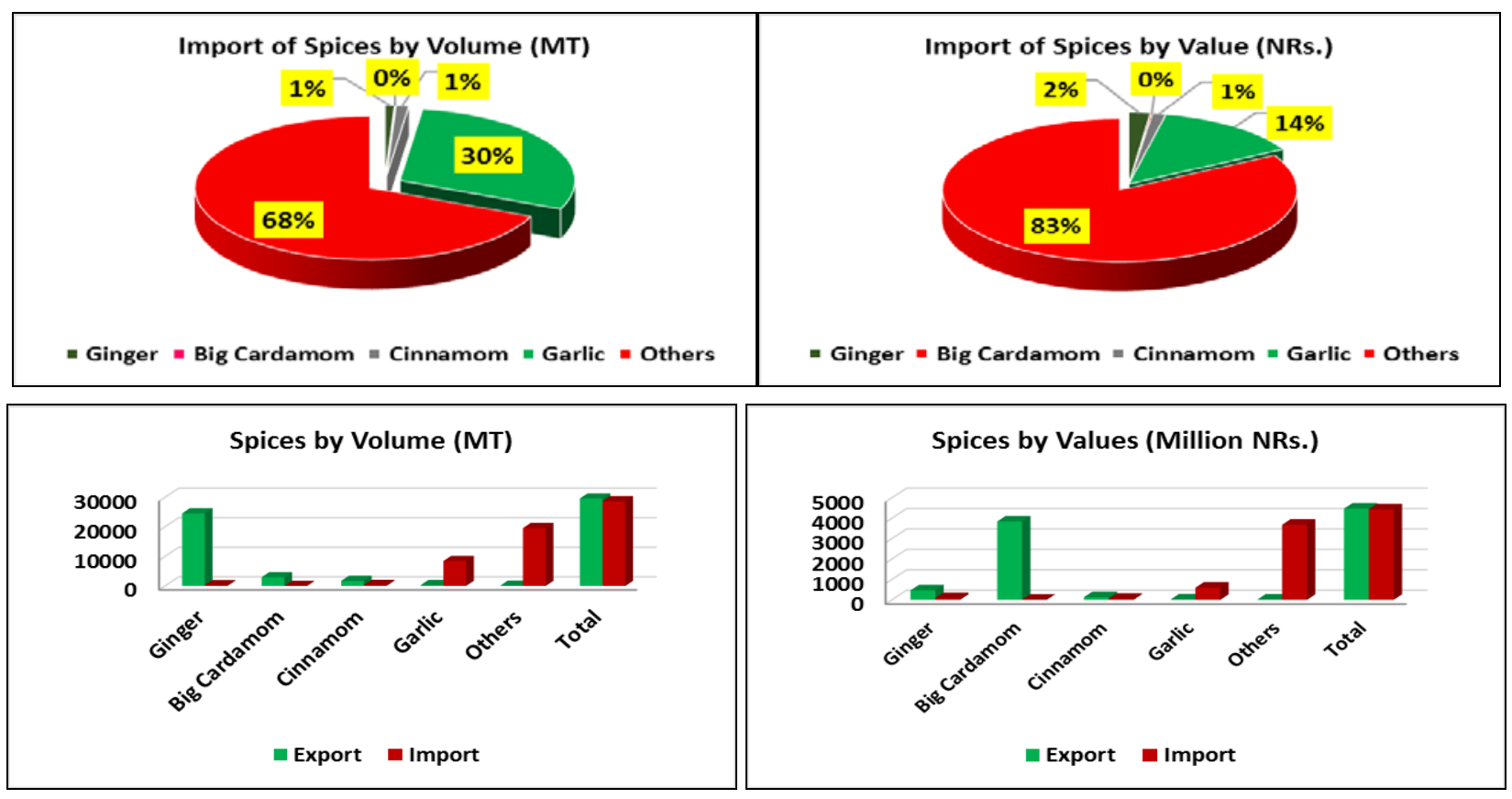

Figure 10. Export and import of spices by volume and values

Table 11. Import and Export of Tea to and from Nepal

\begin{tabular}{|c|c|c|c|c|}
\hline \multirow{2}{*}{ Tea } & \multicolumn{2}{|c|}{ Import } & \multicolumn{2}{c|}{ Export } \\
\cline { 2 - 5 } & Volume (MT) & Values (NRs.) & Volume (MT) & Values (NRs.) \\
\hline Black Tea & 374 & 92760589 & 11120 & 1993529991 \\
\hline Green Tea & 2 & 1002063 & 22 & 13347111 \\
\hline Total & 376 & 93762652 & 11142 & 2006877102 \\
\hline
\end{tabular}

Source: SINA 2015 [4], (1USD $\cong 102$ NRs.)

\section{Export of Tea by Volume (MT)}

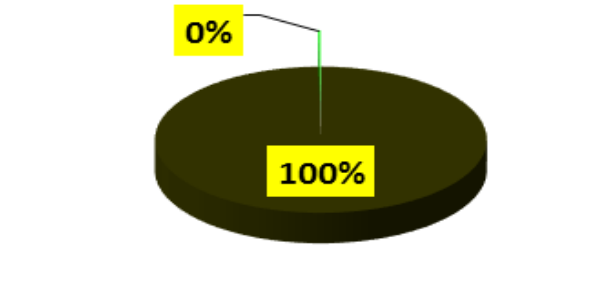

- Black Tea Green Tea

- Black Tea Green Tea

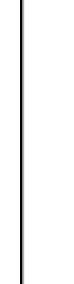

\section{Export of Tea by Values (NRs.)}

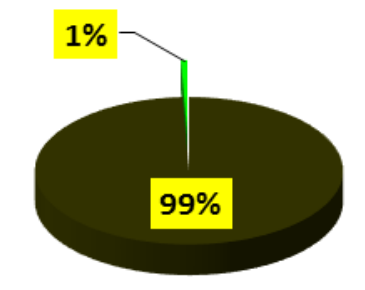

- Black Tea Green Tea

\section{Import of Tea by Volume (MT)}

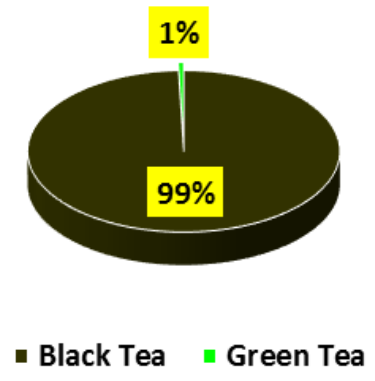

Import of Tea by Values (NRs.)

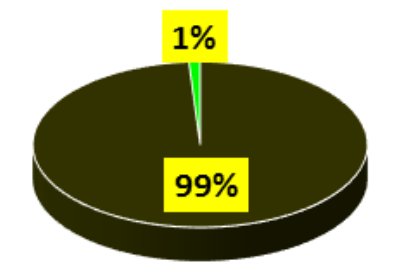

- Black Tea = Green Tea 


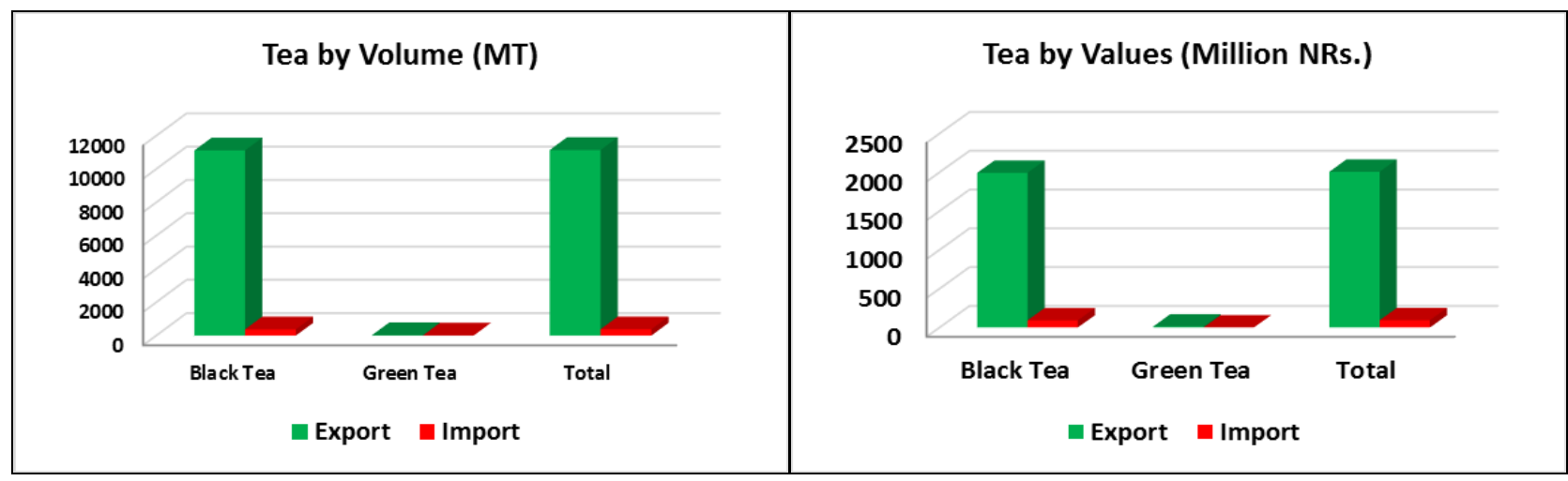

Figure 11. Export and import of tea by volume and values

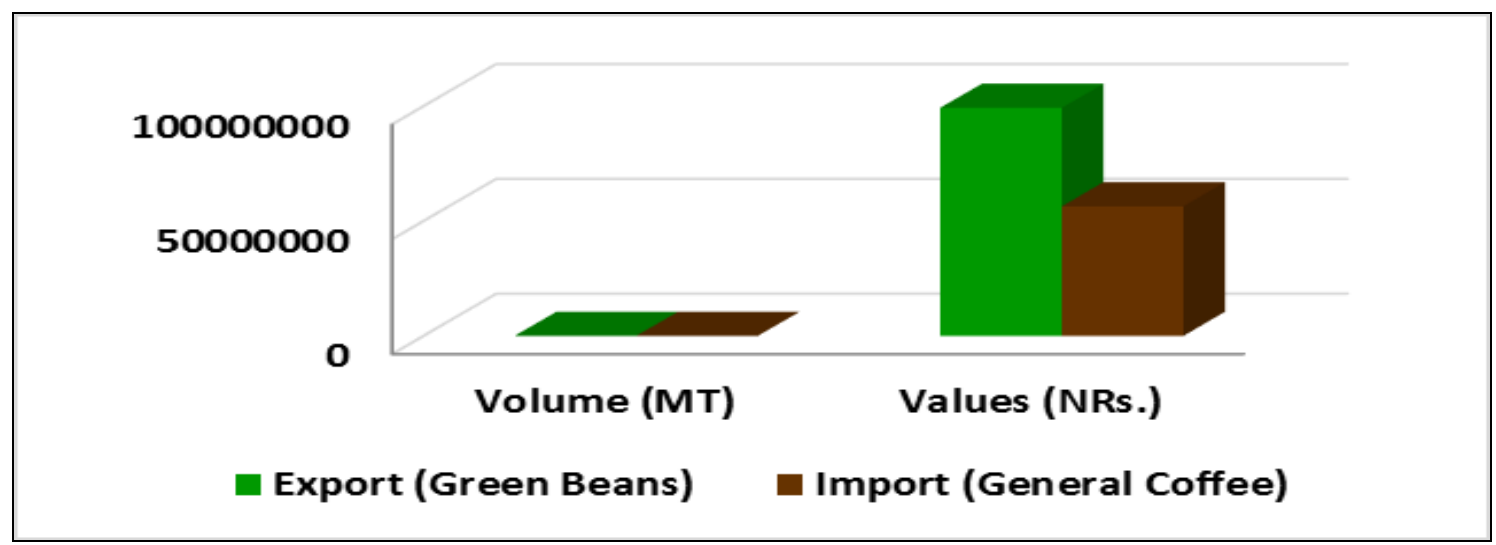

Figure 12. Export and import of coffee by volume and values

Table 12. Import and Export of Coffee to and from Nepal

\begin{tabular}{|c|c|c|}
\hline Coffee & Volume (MT) & Values (NRs.) \\
\hline $\begin{array}{c}\text { Export } \\
\text { (Green Beans) }\end{array}$ & 100 & 99303979 \\
\hline $\begin{array}{c}\text { Import } \\
\text { (General Coffee) }\end{array}$ & 111 & 56456160 \\
\hline
\end{tabular}

Source: SINA 2015 [4], (1USD $\cong 102$ NRs.)

Table 13. Import and Export of flowers to and from Nepal

\begin{tabular}{|c|c|c|c|c|}
\hline \multirow{2}{*}{ Flowers } & \multicolumn{2}{|c|}{ Import } & \multicolumn{2}{c|}{ Export } \\
\cline { 2 - 5 } & Volume (Pcs.) & Values (NRs.) & Volume (Pcs.) & Values (NRs.) \\
\hline Live Plants & 1939920 & 93097906 & 62530 & 2023037 \\
\hline Cut flowers & 557790 & 7030433 & 5512 & 506598 \\
\hline Ornamental Foliage & 21628 & 321271 & 600 & 10580 \\
\hline Total & $\mathbf{2 5 1 9 3 3 8}$ & $\mathbf{1 0 0 4 4 9 6 1 0}$ & $\mathbf{6 8 6 4 2}$ & $\mathbf{2 5 4 0 2 1 5}$ \\
\hline
\end{tabular}

Source: SINA 2015 [4], (1USD $\cong \mathbf{1 0 2}$ NRs.) 

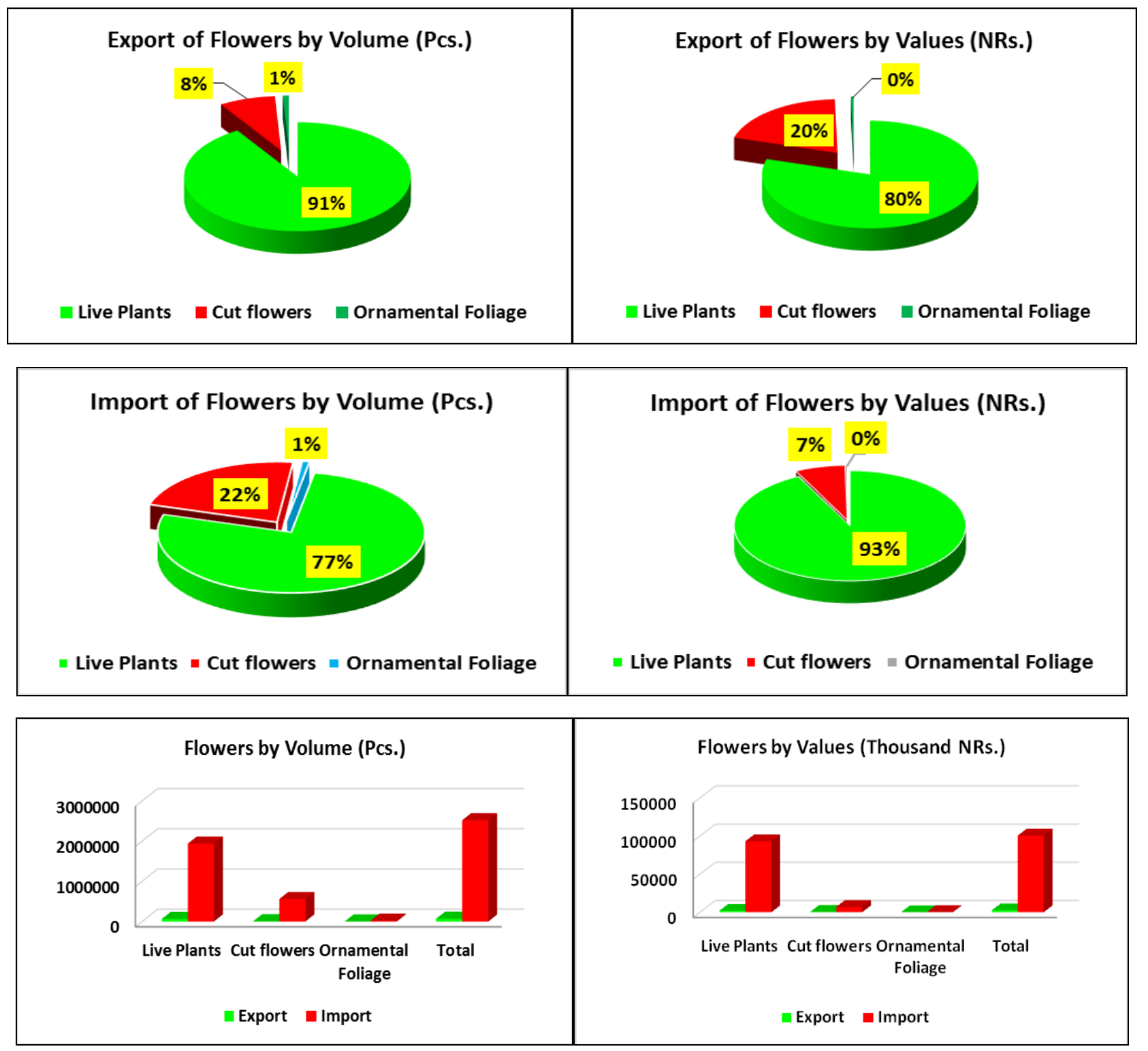

Figure 13. Export and import of flowers by volume and values

Table 14. Global Comparison in Production \& Productivity among leading producers

\begin{tabular}{|c|c|c|c|c|c|c|c|c|}
\hline \multirow{3}{*}{ Crops } & \multirow{2}{*}{\multicolumn{2}{|c|}{$\begin{array}{c}\text { Current Status } \\
\text { Nepal }\end{array}$}} & \multicolumn{6}{|c|}{ Potential } \\
\hline & & & \multicolumn{3}{|c|}{ Production (MT) } & \multicolumn{3}{|c|}{ Productivity (MT/Ha) } \\
\hline & $\begin{array}{l}\text { Production } \\
\text { (MT) }\end{array}$ & $\begin{array}{c}\text { Productivity } \\
\text { (MT/ha) }\end{array}$ & China & India & World & China & India & World \\
\hline Fruits & 992703 & 8.96 & 137066750 & 88977134 & 654449438 & 11.6 & 12.3 & 11.4 \\
\hline Vegetables & 3580085 & 13.41 & 573935000 & 162896911 & 1159889787 & 23.4 & 17.3 & 19.6 \\
\hline Potatoes & 2586287 & 13.13 & 92762496 & 41483000 & NA & 16.8 & 21.8 & NA \\
\hline Spices & 404420 & 6.86 & 97000 & 1496990 & NA & 3.3 & 2.0 & NA \\
\hline Tea & 23187 & 0.89 & 1789753 & 1135070 & NA & 1.0 & 1.9 & NA \\
\hline Coffee & 434 & 0.17 & 92064 & 314000 & NA & 2.4 & 0.9 & NA \\
\hline
\end{tabular}

Source: FAO Website February 2015 (Data for 2012, 2013) \& For India: DAC (Data for 2013-14) for fruits \& vegetables. faostat3.fao.org [9] for potatoes, spices, tea \& coffee. 


\subsection{Coffee}

Nepal exports green beans coffee whereas general coffee is imported in the country. In the export and import point of view the share of both types of coffee is almost same by volume while by values green beans coffee covers more than $40 \%$ in export in comparison to import of general coffee (Table 12) which is a sign of encouragement in the coffee sub-sector.

\subsection{Flowers}

In export, share of live plants is $91 \%$ followed by cut flowers (8\%) and ornamental foliage (1\%) by volume while by values live plants covers $80 \%$ followed by cut flowers (20\%) and ornamental foliage in insignificant amount whereas in import, share of live plants are $77 \%$ followed by cut flowers (22\%) and ornamental foliage (1\%) by volume while by values live plants cover $93 \%$ followed by cut flowers (7\%) and ornamental foliage in insignificant amount. Table 13 aware that much more steps to be taken forward for flourishing the floriculture sub-sector.

\section{Prospects}

\subsection{Comparative Advantage}

The climate in hills and mountains differ from the terrain. During summer, temperature in the hills and mountains is low. Normal season vegetables in hills considered as off-season in terrain and neighboring countries. Off-season vegetables fetch higher price in the market as well. Because of diverse agro-ecological situations in the hills and mountains, different fruits, spices, flowers have niche value as well as it has comparative advantages like production season of citrus is differed from India and Bangladesh, export quality of large cardamom is produced in the eastern hills, niche type of orchids and highland specialty coffee has high demand in the international market, orthodox tea is highly appreciated in the international arena, Gautam, D. M. [3].

As per Statistical Information of Nepalese Agriculture 2014/2015, Nepal's significant horticulture production is in increasing trend despite its comparatively lower productivity. Both in case of fruits \& vegetables, productivity of Nepal (8.96 \& 13.41 ton per hectare respectively) are lower than the productivity of China (11.6 and 23.4 ton per hectare), India (12.3 and 17.3 ton per hectare) and world average (11.4 and 19.6 ton per hectare). During 2013-14, in case of spices basically in large cardamom, Nepal's productivity (6.86 ton per hectare) was better than the China and India (3.3 and 2.0 ton per hectare respectively). Though the comparison of Nepal's horticulture productivity with that of China, the leading producer of fruits \& vegetables, and India does not give identical results but there is a potentiality in case of large cardamom, tea and coffee. In case of large cardamom production Nepal's yield is the best amongst the major producers (Table 14).

\subsection{Employment Opportunity}

The drain of manpower to the overseas is due to unemployment problems in the country. At present situation more than 3,000,000 youths have been deployed in the overseas in search of job. Production, processing and marketing of horticultural crops create employment opportunity to the rural and urban youths. Commercialization of horticulture crops and their value addition generate income to the people, Gautam, D. M. [3].

\subsection{National and International Market}

Nepal has been under the process of rapid urbanization. It is assumed that by 2030 about $50 \%$ of the population will live in the town and cities. This will create a high demand for agricultural commodities in the markets. At present context the import of fruits, vegetables and other high value commodities is increasing every year. Current Import scenario of horticultural crops in values are as such, apple of NRs 1.9 b, Banana of NRs 292 m, Citrus of 129 m, fresh vegetables of NRs $844 \mathrm{~m}$, flowers of NRs $95 \mathrm{~m}$.

In some commodities where import is increasing it can be substituted by producing such commodities within the country such as; mango, banana, onion, potato, chili and other vegetables. On the other hand, by utilizing diverse agro-ecology of hills and mountains various high value commodities can be produced in niche areas and export to other nations. Nepal does have potential scope to export horticultural crops like mandarin, sweet orange, lime and areca nut in fruits; cabbage, peas and tomatoes as off-season vegetables; large cardamom and ginger in spices; tea and coffee in plantation crops; cut flower, orchid, rose and carnation in flower sub-sector, SINA 2015 [4].

\subsection{Government Policies and Plans}

Government of Nepal has always prioritized for horticulture development in periodic plans. In the 20 year Agriculture Perspective Plan (APP, 1994/95-2014/15), government outlined the broad policy to transform subsistence agriculture into commercial one and priorities given to the horticultural crops such as apple in mountain; citrus, coffee, tea and vegetable seeds in mid-hill and mango, banana and fresh vegetables in terrain. The policies emphasize to facilitate market oriented high value commodities, contribute internal and export markets through agro-based industries and poverty reduction through commercialization of horticulture.

Likewise, government formulated Nepal Trade Integration Strategy (NTIS) in 2010, which identified seven agro-food i.e., ginger, tea, large cardamom, lentil, honey, noodles and 
medicinal herbs for export potentialities, out of which three are horticulture commodities.

The government has endorsed Agriculture Development Strategy (ADS) in 2015 with the vision of a competitive, sustainable inclusive agriculture sector that contribute to economic growth, improved livelihood, and food and nutrition security. It will accelerate agriculture sector growth through four strategic components including improved governance, productivity, commercialization and competitiveness. Priority is given to inclusiveness (both social and geographical), sustainability (both natural resources and economical) and connectivity to market infrastructures (agricultural roads, collection centers, packing houses, market centers etc.), information infrastructures and ICT, and power infrastructure, ADS 2015 [2].

\subsection{Identified Horticultural Crops}

The climate of terrain (lower belt), mid-hills and high hills are suitable for the production of many kinds of fruits and high value horticulture commodities such as mango, banana, papaya, areca nut, tea, cut flowers, vegetables and potatoes in terrain; mandarin, sweet orange, lime, pomegranate, kiwi, coffee, tea, large cardamom, ginger, cut-flowers, vegetables and potatoes in mid-hills and apple, walnut, apricot, peach, pear, plum, vegetables and potatoes in high-hills, Gautam, D. M. [3].

\section{Challenges}

Despite of greater scope and potentiality there are various constraints for the production of horticulture crops commercially, Gautam, D. M. [3]:

\subsection{Subsistence Farming}

Farming system in Nepal is conventional and subsistence type. Each farmer grows most of the crops as per need of his family. The scattered form of farming imposed a greater constraint in marketing of horticultural crops. From sustainable point of view growing all crops is important. For commercial production it should be specialized to particular crop. The low volume of products and absence of consolidated marketing system create the great setback for export.

\subsection{Lack of Systematic Marketing System}

In Nepal marketing system is a major problem. Farmers are encouraged to grow vegetables, fruits and high value crops without sustainable market and marketing system. Productions without market create embarrassing situations to the growers and discourage production. Producers face problems due to lack of transportation facilities such as marketing of apple from high hill regions and citrus fruits in the mid-hill regions.

\subsection{Lack of Physical Infra-structure}

In remote areas inaccessibility to the road is the major problem to produce horticultural commodities. The production of most of the fruits is seasonal in nature. The production areas are in remote and the bulk of production is confined to a particular limited time. Bulk production of seasonal crops in a limited period leads to fetch poor market price due to lack of proper storage and processing units. Lack of cleaning, grading, sorting, fumigation, waxing and other packing house operations decrease export quality of the horticultural products. In many instances, inferior qualities are processed to different product such as juice, jam jellies and beverages. In some crops production without processing is useless such as coffee, tea etc. Because of growing transaction the size of existing market has squeezed and is not enough.

\subsection{Human Resource Management}

In Nepal the well trained manpower are not enough. There is lack of subject matter specialists (SMS) in spice crops, tea, and coffee sub-sector. In the field of postharvest handling and processing of horticultural crops skilled manpower is still lacking. Overseas job creates shortage of youth labor in the country as well. Due to foreign job migration of people from rural areas to urban areas is in increasing trend.

\subsection{Low Priority in Investment}

Poor economic status of Nepalese people cannot support big projects of commercial production and processing of horticultural crops. Inadequate investment of government in horticulture sector is also a great challenge. Foreign investor or donors have less priority in fruit sub-sector for investments.

\section{Strategies}

The government of Nepal has made efforts to promote the horticulture sector in short as well as in long term plans, yet some deficiencies are experienced which are to be addressed in future:

- Emphasis should be given to niche fruits, plantation crops, flowers and spice crops production in larger areas.

- $\quad$ Research institutes should be strengthened to develop the hybrid varieties of horticultural crops especially vegetables.

- Big production blocks should be created and strengthened in fruit sub-sector. 
- The plantation areas of tea and coffee should be expanded because demand of coffee (green beans) and green tea in international market is high.

- Processing units should be established for the promotion of ginger, areca nut and large cardamom.

- Big storage house facilities should be provided for year round supply and price stabilization.

- Capacity enhancement for the horticulturists and frontline extension workers need to be strengthened.

- Foreign aid/ investment need to be mobilized through single door policy.

- Implementation of crop insurance policy should be assured to commercial farmers.

- Sanitary and phyto-sanitary (SPS) measures should be followed strictly for exportable commodities.

\section{REFERENCES}

[1] Agriculture Diary. Agriculture Information \& Communication Center, Ministry of Agricultural Development, Government of Nepal, Harihar Bhawan, Lalitpur, 11-14, 2015

[2] Agriculture Development Strategy (ADS). Draft Vision Report, Government of Nepal, Ministry of Agricultural Development, Singhdurbar, Kathmandu, 22-26, 2015
[3] D. M. Gautam, PhD. Commercialization in Agriculture: Prospects, Challenges and Strategies. Nepal Horticulture Society, Kathmandu, Nepal, Nepalese Horticulture, Vol. 7, 27-32, 2012

[4] Statistical Information of Nepalese Agriculture (SINA). Government of Nepal, Ministry of Agricultural Development, Agri-Business Promotion and Statistics Division, Singhdurbar, Kathmandu, 16-17; 50-95, 2015.

[5] Annual Progress Report. Government of Nepal, Ministry of Agricultural Development (MOAD), Agri-Business Promotion and Statistics Division, Singhdurbar, Kathmandu, 108-111, 2015.

[6] Six Decades of Horticulture Development in Nepal (Silver Jubilee Special-International Horticulture Conference, 2015), Nepal Horticulture Society (NHS), Kathmandu, Nepal, 1-16; 186-209, 2016.

[7] Poudyal, B. K., PhD and L. N. Acharya. Reformation of Horticulture Institutions in Nepal. Proceedings of the eighth National Horticulture Seminar on Horticulture Development towards the Pace of National Economic Growth. Nepal Horticulture Society, Kathmandu, Nepal, Vol. 8, 105-120, 2013

[8] Thapa, M. B., K. Adhikari, S. Dhimal. Trade Flow Analysis of Large Cardamom in Eastern Region. Ministry of Agricultural Development (MOAD), Singhdurbar, Kathmandu, 24-29, 2015.

[9] http://www.faostat3.fao.org. 